\title{
Black-white racial disparities in household food insecurity from 2005 to 2014, Canada
}

\author{
Simran Dhunna ${ }^{1}$ (D) Valerie Tarasuk ${ }^{2}$ \\ Received: 31 August 2020 / Accepted: 3 May 2021 / Published online: 15 June 2021 \\ (C) The Canadian Public Health Association 2021
}

\begin{abstract}
Objectives To understand the differential vulnerability to household food insecurity of the Black population as compared with white counterparts in Canada.

Methods Using data for households with Black and white respondents in pooled Canadian Community Health Survey cycles from 2005 to 2014, the 18-question Household Food Security Survey Module was analyzed $(N=491,400)$. Bivariate and multivariate logistic and multinomial regression models were run using respondent's race, immigration status, and six wellestablished predictors of household food insecurity in the general population. Additional multivariable logistic regression models were run, with race interacted with each predictor individually to yield predicted probabilities.

Results The weighted prevalence of household food insecurity was $10.0 \%$ for white respondents and $28.4 \%$ for Black respondents. The odds of Black households being food-insecure as compared with white households fell from 3.56 (95\% CI: 3.30-3.85) to 1.88 (95\% CI: 1.70-2.08) with adjustment for household socio-demographic characteristics. In contrast with white households, there was relative homogeneity of risk of food insecurity among Black subgroups defined by immigration status, household composition, education, and province of residence. Homeownership was associated with lower probabilities of food insecurity for Black and white households, but the probability among Black owners was similar to that for white renters $(14.7 \%$ vs. $14.3 \%)$. Black households had significantly higher predicted probabilities of food insecurity than their white counterparts across all main sources of household income except child benefits and social assistance.

Conclusion Being racialized as Black appears to be an overriding factor shaping vulnerability to food insecurity for the Black population in Canada. Future research and public policy on food insecurity should seriously consider the role of racism at the systemic and institutional levels.
\end{abstract}

\section{Résumé}

Objectifs Comprendre la vulnérabilité différentielle de la population noire à l'insécurité alimentaire des ménages par rapport à la population blanche au Canada.

Méthode À l'aide des données sur les ménages comptant des répondants noirs et blancs dans les cycles combinés de l'Enquête sur la santé dans les collectivités canadiennes de 2005 à 2014, nous avons analysé les 18 questions du Module d'enquête sur la sécurité alimentaire des ménages $(N=491400)$. Nous avons exécuté des modèles de régression logistique et multinomiale bivariés et multivariés en utilisant la race des répondants, leur statut d'immigration et six variables prédictives bien établies de l'insécurité alimentaire des ménages dans la population générale. D'autres modèles de régression logistique multivariés ont aussi été exécutés, avec des interactions entre la race et chaque variable prédictive afin de produire des probabilités prédites.

Résultats La prévalence pondérée de l'insécurité alimentaire des ménages était de $10 \%$ pour les répondants blancs et de $28,4 \%$ pour les répondants noirs. Après la prise en compte du profil sociodémographique des ménages, la probabilité d'insécurité

Simran Dhunna

simran.dhunna@mail.utoronto.ca; dhunnasimran@gmail.com

1 Dalla Lana School of Public Health, University of Toronto, Toronto, ON, Canada

2 Department of Nutritional Sciences, Faculty of Medicine, University of Toronto, Toronto, ON, Canada 
alimentaire chez les ménages noirs comparativement aux ménages blancs est passée de 3,56 (IC de $95 \%: 3,30-3,85$ ) à 1,88 (IC de $95 \%: 1,70-2,08)$. Contrairement aux ménages blancs, le risque d'insécurité alimentaire était relativement homogène dans les sous-groupes noirs définis selon le statut d'immigration, la composition du ménage, l'instruction et la province de résidence. L'accession à la propriété était associée à une plus faible probabilité d'insécurité alimentaire tant dans les ménages noirs que dans les ménages blancs, mais la probabilité chez les propriétaires noirs était semblable à celle des locataires blancs $(14,7 \%$ c. $14,3 \%)$. Les probabilités prédites d'insécurité alimentaire étaient sensiblement plus élevées dans les ménages noirs que dans les ménages blancs pour toutes les sources de revenu des ménages sauf les prestations pour enfants et l'aide sociale.

Conclusion Le fait d'être racisé comme une personne noire semble être un facteur déterminant de la vulnérabilité à l'insécurité alimentaire dans la population noire au Canada. Les études et les politiques publiques futures sur l'insécurité alimentaire devraient envisager sérieusement le rôle du racisme à l'échelle systémique et institutionnelle.

Keywords Food insecurity $\cdot$ Racial inequality $\cdot$ Anti-Black racism

Mots-clés Insécurité alimentaire $\cdot$ inégalités raciales $\cdot$ racisme anti-Noirs

\section{Introduction}

Household food insecurity - the inadequate or insecure access to food due to financial constraints - is increasingly recognized as a serious public health problem in many high-income countries. In Canada, food insecurity has been linked to increased risk of chronic physical and mental health problems (JessimanPerreault \& McIntyre, 2017; McIntyre et al., 2012b), increased health care utilization and costs (Men et al., 2020b), and higher mortality rates (Men et al., 2020a). Despite this evidence, food insecurity rates in Canada remain persistently high, with $12.7 \%$ of households having experienced some level of food insecurity in 2017-2018 (Tarasuk \& Mitchell, 2020). Food insecurity is now escalating through the COVID-19 pandemic (Statistics Canada, 2020).

After more than two decades of population measurement in Canada, the socio-demographic and geographic correlates of food insecurity are well understood. Vulnerability is highest among households characterized by low incomes; reliance on social assistance, Employment Insurance, or workers' compensation; lower educational attainment; renting rather than owning one's dwelling; Aboriginal status; and the presence of children (Tarasuk et al., 2019b). In contrast, households reliant on old-age pensions and other retirement income sources, immigrant households, and those residing in Quebec appear to be protected against food insecurity, once other socio-demographic factors are taken into account (Tarasuk et al., 2019b). Although population survey data also indicate marked differences in food insecurity prevalence by race (Tarasuk \& Mitchell, 2020), this has not been a focus of study in Canada to date.

Population monitoring of food insecurity in the United States routinely documents the disproportionate burden of household food insecurity among the non-Hispanic Black population in that country (Coleman-Jensen et al., 2019), and several US scholars have noted the effects of racial discrimination in relation to this burden (Burke et al., 2018; Nam et al., 2015). In Canada, where Black people comprise a much smaller proportion of the population (3.5\% in 2016) (Statistics Canada, 2016), there has been no focused examination of the relationship between race and vulnerability to food insecurity. However, two studies in Canada have reported elevated odds of household food insecurity in Black subgroups, independent of socio-economic circumstances (McIntyre et al., 2012a; Tarasuk et al., 2019b), highlighting the need for a more focused investigation of Black-white disparities in food insecurity in Canada. Using pooled data from the Canadian Community Health Survey from 2005 to 2014, we set out to explore how Black and white populations in Canada differ in their vulnerability to household food insecurity. More specifically, the purpose of our study was to (1) examine the association of Blackwhite racial identity and prevalence and severity of household food insecurity, and (2) understand how racialized vulnerability manifests differently for a set of key socio-demographic predictors.

\section{Methods}

\section{Data source and design}

The Canadian Community Health Survey (CCHS) is a crosssectional population-representative survey of individuals aged 12 years and older, excluding individuals who are full-time members of the Canadian Forces, reside in prisons or care facilities, or live on First Nations Reserves, Crown Lands, or in some remote regions of Quebec. Overall, these exclusions represent less than $3 \%$ of the population. Our study was limited to households with complete data on the Household Food Security Survey Module (HFSSM) and respondent's ethnoracial identity as either Black or white. Five cycles were pooled from 2005 to 2014 to yield a sample of 549,247 Black or white respondents in total, of which 491,364 had complete data in the HFSSM. CCHS cycles after 2014 were excluded because changes in the sampling design in 2015 limit the comparability of more recent cycles. 
The HFSSM was developed by the US Department of Agriculture (USDA) and is used to monitor food insecurity at the household level in the USA and Canada. This wellvalidated metric comprises 18 questions that elucidate the severity of household food insecurity over the past 12 monthsthe health outcome in this study. Household food insecurity was assessed both as a binary variable (food secure/food insecure) and a four-level categorical variable (food secure, marginally food-insecure, moderately food-insecure, and severely food-insecure). Marginal, moderate, and severe food insecurity were determined based on the number of affirmative responses, following Health Canada's updated classification system (Government of Canada, 2020). The binary classification of food insecurity included marginal, moderate, and severe food insecurity.

Established socio-demographic predictors of household food insecurity in Canada were included in descriptive analyses and modeling (Tarasuk et al., 2019a). Household-level predictors included household composition, before-tax household income, housing tenure, highest level of education in the household, main household income source, and province/territory. The latter variable was coded as "Ontario," "Quebec," and "Other provinces and territories," in order to tease apart established differences in household food insecurity risk between Quebec and Ontario (Tarasuk et al., 2019a). Household income was adjusted for household size by dividing by the square root of the number of individuals in the household. Given that the main predictor under study was race, two other variables measured only at the respondent level were included: ethno-racial self-identification as either Black or white, and immigration status (a combination of two variablesborn in Canada or abroad, and number of years in Canada after immigration). The CCHS collects information on ethno-racial identity by asking respondents if they belong to one or more "racial or cultural groups" on a list codified under the Employment Equity Act, within which one option is "Black" (Statistics Canada, 2017). These two variables were considered proxies for the household.

For all categorical variables, the category with the highest number of observations operated as the reference group. Approximately $30 \%$ of the sample did not report income, and Statistics Canada imputed values for this group. A binary variable was included to denote imputed incomes. For other variables, missing responses were coded in order to minimize sample loss and preserve the information provided by each observation.

\section{Statistical analysis}

We created socio-demographic profiles of the food-secure and food-insecure households by race, expressing variables under study as proportions and means. To determine the relationship between binary household food insecurity and Black-white race, first, logistic regression models were conducted to generate unadjusted and adjusted odds ratios of food insecurity. The adjusted model controlled for all of the nine aforementioned socio-demographic variables. Second, to identify the relationship between race and severity of food insecurity, unadjusted and adjusted multinomial logistic regression models were run, regressing the four-level household food insecurity status variable on socio-demographic characteristics.

Finally, in order to test whether the relationship between household food insecurity and each socio-demographic variable identified as a potent predictor of the outcome differed by race, six additional logistic regression models adjusting for the socio-demographic variables were run, with race interacted with each of the six variables individually: household composition, household education, housing tenure, main income source, immigration status, and province. Predicted probabilities from the margins based on these six adjusted models were then estimated. While predicted probabilities represent an absolute measure of association, odds ratios are relative measures. Odds ratios are useful in describing the strength of an association but tend to overestimate the magnitude of the association when the outcome is not rare (Persoskie \& Ferrer, 2017). Thus, in presenting the results of the interactions, we focus on the predicted probabilities because they enable us to contrast the likelihood that food-insecure households are Black or white with the likelihood that food-insecure households exhibit any of the characteristics in the five other socio-demographic variables. Predicted probabilities are also flexible in their analysis, in that there is no typical "reference group" when attempting to determine the statistical difference between two probabilities. All analyses were conducted with Stata 14.0 (StataCorp, College Station, Texas, USA), using SURVEY commands with household weights provided by Statistics Canada. Institutional ethics approval for this study was received from the Human Research Ethics Board of the University of Toronto.

\section{Findings}

The weighted prevalence of household food insecurity in the overall sample was $10.6 \%$ (not shown); it was $10.0 \%$ for white respondents and $28.4 \%$ for Black respondents. Figure 1 shows the distribution of the four-level household food security outcome by race. Table 1 presents the distribution of weighted household food insecurity status by race and sociodemographic characteristics for the entire sample.

\section{Logistic regression: Black-white racial disparities}

Table 2 presents crude and adjusted odds ratios of household food insecurity for the socio-demographic variables from Table 1. An unadjusted model with race and household food 
Table 1 Socio-demographic characteristics of households, by weighted prevalence of household food insecurity and race, Canada, 2005-2014 $(N=491,364)$

\begin{tabular}{|c|c|c|c|c|c|c|c|}
\hline & \multicolumn{3}{|c|}{ Total $(N=491,364)$} & \multicolumn{2}{|l|}{ White } & \multicolumn{2}{|l|}{ Black } \\
\hline & All & White & Black & Food secure & Food insecure & Food secure & Food insecure \\
\hline & NA & 97.2 & 2.8 & 90.0 & 10.0 & 71.6 & 28.4 \\
\hline \multicolumn{8}{|l|}{ Household composition ${ }^{\mathrm{a}}(\%)$} \\
\hline Unattached, living alone or with others & 32.8 & 30.0 & 11.0 & 85.9 & 14.1 & 69.5 & 30.5 \\
\hline Couple alone, no children & 29.3 & 33.0 & 33.0 & 95.3 & 4.7 & 85.2 & 14.8 \\
\hline Couple with children & 21.3 & 21.0 & 24.0 & 91.5 & 8.5 & 76.4 & 23.6 \\
\hline Female lone parent & 4.4 & 4.0 & 17.0 & 70.9 & 29.1 & 52.3 & 47.7 \\
\hline Male lone parent & 1.0 & 1.0 & 1.0 & 84.2 & 15.8 & 59.5 & 40.5 \\
\hline Other & 10.8 & 11.0 & 13.0 & 92.3 & 7.7 & 83.2 & 16.8 \\
\hline Missing & 0.4 & 0.0 & 1.0 & 88.2 & 11.8 & 67.7 & 32.3 \\
\hline Household income $^{\mathrm{b}}($ mean \pm SEM) & $52.36 \pm 0.08$ & $52.8 \pm 0.081$ & $36.86 \pm 0.45$ & $55.6 \pm 0.09$ & $27.8 \pm 0.16$ & $42.7 \pm 0.55$ & $22.2 \pm 0.47$ \\
\hline \multicolumn{8}{|l|}{ Main source of household income (\%) } \\
\hline Wage/salary/self-employment & 67.1 & 67.0 & 73.0 & 91.2 & 8.8 & 76.3 & 23.7 \\
\hline Seniors' income $\mathrm{e}^{\mathrm{c}}$ & 21.9 & 22.0 & 7.0 & 93.6 & 6.4 & 81.1 & 19.0 \\
\hline Employment insurance/workers' compensation & 1.0 & 1.0 & 2.0 & 69.5 & 30.5 & 36.7 & 63.3 \\
\hline Child support/child tax benefit & 0.3 & 0.0 & 1.0 & 52.7 & 47.3 & 41.9 & 58.1 \\
\hline Social assistance & 2.6 & 2.0 & 8.0 & 36.0 & 64.0 & 31.3 & 68.7 \\
\hline Other/none & 2.7 & 3.0 & 3.0 & 82.4 & 17.6 & 61.9 & 38.1 \\
\hline Missing & 4.6 & 5.0 & 5.0 & 93.0 & 7.0 & 80.7 & 19.4 \\
\hline \multicolumn{8}{|l|}{ Household education (\%) } \\
\hline Post-secondary degree & 68.6 & 69.0 & 68.0 & 92.1 & 7.9 & 75.2 & 23.8 \\
\hline No post-secondary degree & 26.9 & 27.0 & 25.0 & 84.9 & 15.1 & 60.0 & 40.0 \\
\hline Missing & 4.5 & 4.0 & 7.0 & 88.5 & 11.5 & 68.6 & 31.4 \\
\hline \multicolumn{8}{|l|}{ Housing tenure $(\%)$} \\
\hline Homeowner & 70.9 & 72.0 & 40.0 & 94.6 & 5.4 & 85.8 & 14.2 \\
\hline Renter & 28.9 & 28.0 & 59.0 & 78.1 & 21.9 & 61.8 & 38.2 \\
\hline Missing & 0.2 & 0.0 & 0.0 & 90.0 & 10.0 & 78.7 & 21.4 \\
\hline \multicolumn{8}{|l|}{ Province $(\%)$} \\
\hline Ontario & 37.8 & 37.0 & 60.0 & 90.2 & 9.8 & 71.4 & 28.6 \\
\hline Quebec & 29.3 & 29.0 & 26.0 & 90.2 & 9.8 & 69.5 & 30.5 \\
\hline Other & 33.0 & 34.0 & 14.0 & 89.5 & 10.5 & 76.1 & 23.9 \\
\hline \multicolumn{8}{|l|}{ Immigration status (\%) } \\
\hline Canadian-born & 86.3 & 88.0 & 27.0 & 89.6 & 10.4 & 71.8 & 28.2 \\
\hline Recent immigrant ( $0-10$ years $)$ & 2.5 & 2.0 & 26.0 & 89.0 & 11.0 & 66.1 & 33.9 \\
\hline Non-recent immigrant $(11+$ years $)$ & 11.0 & 10.0 & 45.0 & 93.2 & 6.8 & 74.6 & 25.5 \\
\hline Missing & 0.3 & 0.0 & 2.0 & 89.2 & 10.8 & 72.8 & 27.2 \\
\hline \multicolumn{8}{|l|}{ Imputed income } \\
\hline Reported income & 72.6 & 73.0 & 70.0 & 89.4 & 10.6 & 70.5 & 29.6 \\
\hline Imputed income & 27.5 & 27.0 & 30.0 & 91.5 & 8.5 & 74.3 & 25.7 \\
\hline \multicolumn{8}{|l|}{ CCHS cycle } \\
\hline $2005-2006$ & 21.1 & 21.0 & 21.0 & 90.4 & 9.6 & 71.4 & 28.6 \\
\hline $2007-2008$ & 18.5 & 19.0 & 14.0 & 90.0 & 10.0 & 70.4 & 29.6 \\
\hline $2009-2010$ & 21.0 & 21.0 & 22.0 & 90.5 & 9.5 & 71.5 & 28.6 \\
\hline 2011-2012 & 21.5 & 21.0 & 21.0 & 89.2 & 10.8 & 73.0 & 27.0 \\
\hline 2013-2014 & 18.0 & 18.0 & 22.0 & 89.7 & 10.3 & 71.3 & 28.7 \\
\hline
\end{tabular}

a Households identified as having children were those with at least one person under the age of 18 . All household categories also may include "others," including children 18 years of age and older

${ }^{\mathrm{b}}$ Household income ('000s) is before-tax income, adjusted for family size by dividing by the square root of household size

' Seniors' income includes pension, Old Age Security, and dividends

insecurity yields an OR of 3.56 (95\% CI: 3.30-3.85). Adjusting for socio-demographic and household characteristics substantively reduced the measure of association for race, but still, Black-respondent households in Canada had 1.88 times the odds of food insecurity compared with whiterespondent households (95\% CI: 1.70-2.08).

\section{Black-white disparity across severity of household food insecurity}

The crude and adjusted odds ratios of marginal, moderate, and severe household food insecurity relative to food insecurity are presented for each of the socio-demographic variables included in the logistic regression models. In the 
Fig. 1 Prevalence of four-level household food insecurity by racial identity

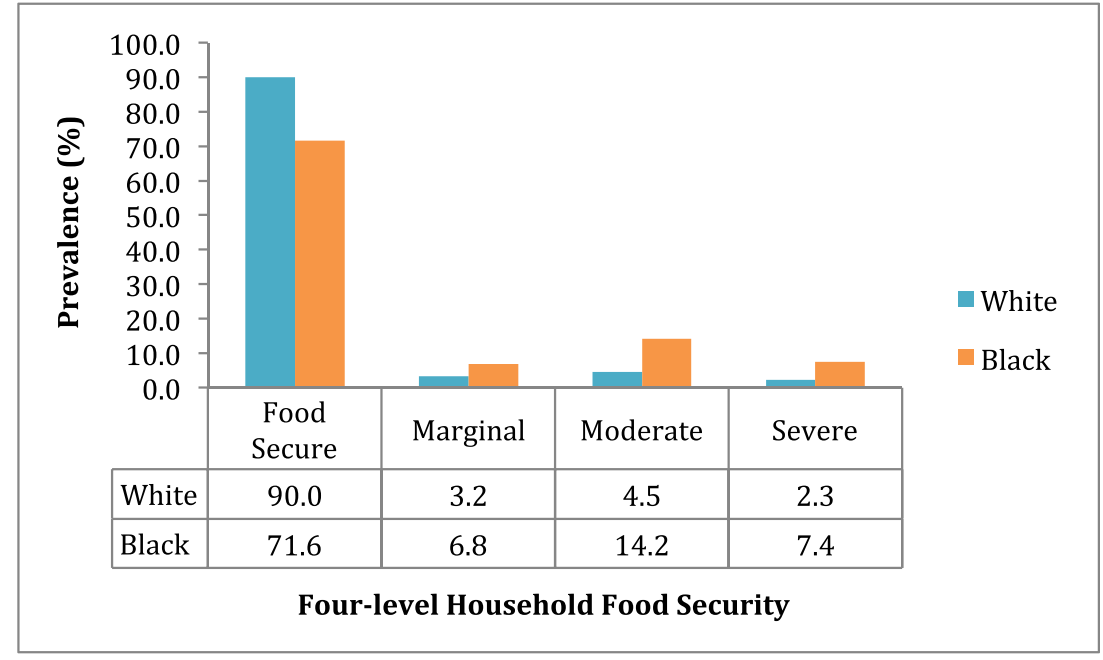

crude multinomial regression, Black households had elevated odds of food insecurity compared with white households, a magnitude that was less for marginal food insecurity than for moderate and severe food insecurity: 2.65 for marginal food insecurity (95\% CI: 2.31-3.04), 3.99 for moderate food insecurity (95\% CI: 3.59-4.43), and 4.01 for severe food insecurity (95\% CI: 3.50-4.59) (Table 3 in the Appendix). When adjusting for the aforementioned socio-demographic variables, the odds of marginal food insecurity for Black households compared with white households reduced to 1.62 (95\% CI: 1.39-1.90); for moderate food insecurity, to 2.02 (95\% CI: $1.77-$ 2.30); and for severe food insecurity, to 1.99 (95\% CI: 1.68-2.37) (Table 4 in the Appendix).

\section{Differential risk profiles between Black and white households}

Figure 2 presents the predicted probabilities of household food insecurity for six multivariable logistic regression models that each have the socio-demographic variables, but different statistical interactions with race. The odds ratios from these logistic regression models are presented in Table 5 in the Appendix.

Among white households, being a recent or non-recent immigrant was protective against household food insecurity compared with being Canadian-born, but there was no statistically significant difference in predicted probability of household food insecurity by immigration status for Black households (Fig. 2a). All Black households regardless of immigration status had a significantly greater predicted probability compared with their white counterparts. Notably, $71 \%$ of individuals in the Black sample were immigrants, compared with $12 \%$ of the white population (Table 1).
Among white households, couples alone with no children had the lowest predicted probability of food insecurity, while female lone-parent households had the highest (Fig. 2b). The predicted probabilities of Black subgroups ranged from $16.8 \%$ to $18.9 \%$, illustrating little heterogeneity between Black household types. Each Black subgroup had a significantly higher probability of household food insecurity compared with their white counterpart, save male lone parents and households with missing data.

For main household income source, Black subgroups had significantly higher predicted probabilities of food insecurity than their white counterparts, with the exception of households reliant on child support or child tax benefit, and social assistance (Fig. 2c). Households reliant on seniors' incomes were the most protected within each racial group. However, the probability of Black households on seniors' income matched that of white households reliant on income from wages/ salaries or self-employment.

Black households in each education subgroup had significantly higher predicted probabilities of food insecurity than their white counterparts (Fig. 2d). Black households in which the highest level of education was "no postsecondary degree" had the highest probability of food insecurity, while white households with someone with a post-secondary degree were most protected. Within each racial group, there were no significant differences in probability based on household education.

White home-owning households had the lowest probability of food insecurity, while Black renters had a nearly three-fold greater probability $(7.5 \%$ versus $20.7 \%$, respectively) (Fig. 2e). The probability of household food insecurity was nearly identical for white renters and Black homeowners. 
Table 2 Crude and adjusted odds of household food insecurity in relation to socio-demographic characteristics, Canada, $(N=491,364)$

\begin{tabular}{|c|c|c|}
\hline & Crude OR $(95 \% \mathrm{CI})$ & Adjusted OR $(95 \% \mathrm{CI})$ \\
\hline \multicolumn{3}{|l|}{ Race } \\
\hline White & 1 & 1 \\
\hline Black & $3.56(3.30-3.85)$ & $1.88(1.70-2.08)$ \\
\hline \multicolumn{3}{|l|}{ CCHS cycle } \\
\hline $2005-2006$ & 1 & 1 \\
\hline $2007-2008$ & $1.03(0.99-1.08)$ & $1.11(1.06-1.16)$ \\
\hline 2009-2010 & $0.99(0.95-1.03)$ & $1.07(1.01-1.12)$ \\
\hline $2011-2012$ & $1.12(1.07-1.18)$ & $1.23(1.17-1.30)$ \\
\hline $2013-2014$ & $1.09(1.04-1.15)$ & $1.21(1.15-1.28)$ \\
\hline \multicolumn{3}{|l|}{ Immigration status } \\
\hline Canadian-born & 1 & 1 \\
\hline Recent immigrant ( $0-10$ years) & $1.83(1.67-2.01)$ & $0.70(0.63-0.79)$ \\
\hline Non-recent immigrant $(11+$ years $)$ & $0.84(0.80-0.89)$ & $0.78(0.73-0.83)$ \\
\hline Missing & $1.49(1.05-2.13)$ & $0.83(0.58-1.19)$ \\
\hline \multicolumn{3}{|l|}{ Highest level of household education } \\
\hline Post-secondary degree & 1 & 1 \\
\hline No post-secondary degree & $2.04(1.98-2.11)$ & $1.08(1.04-1.12)$ \\
\hline Missing & $1.56(1.46-1.66)$ & $1.29(1.20-1.39)$ \\
\hline \multicolumn{3}{|l|}{ Household composition } \\
\hline Couple alone, no children & 1 & 1 \\
\hline Unattached & $3.34(3.20-3.49)$ & $1.51(1.44-1.59)$ \\
\hline Couple with children & $1.94(1.85-2.04)$ & $1.42(1.34-1.49)$ \\
\hline Female lone parent & $8.90(8.38-9.46)$ & $1.84(1.71-1.98)$ \\
\hline Male lone parent & $3.91(3.34-4.58)$ & $1.59(1.37-1.85)$ \\
\hline Other household types & $1.70(1.60-1.81)$ & $1.35(1.27-1.44)$ \\
\hline Missing & $2.94(2.40-3.61)$ & $1.63(1.29-2.06)$ \\
\hline Household income & $0.95(0.95-0.96)$ & $0.96(0.96-0.96)$ \\
\hline \multicolumn{3}{|l|}{ Imputed income } \\
\hline Reported & 1 & 1 \\
\hline Imputed & $0.79(0.77-0.82)$ & $0.73(0.70-0.76)$ \\
\hline \multicolumn{3}{|l|}{ Main household income source } \\
\hline Wage/salary or self-employed & 1 & 1 \\
\hline Seniors' income (pension, Old Age Security, dividends) & $0.69(0.66-0.71)$ & $0.38(0.36-0.40)$ \\
\hline Workers' compensation or employment insurance & $4.64(4.24-5.08)$ & $1.71(1.55-1.89)$ \\
\hline Child support or child tax benefit & $9.27(7.73-11.13)$ & $1.68(1.37-2.06)$ \\
\hline Social assistance & $17.86(16.73-19.06)$ & $2.82(2.62-3.05)$ \\
\hline Other or none & $2.22(2.05-2.39)$ & $0.88(0.80-0.95)$ \\
\hline Missing & $0.78(0.72-0.85)$ & $0.44(0.40-0.48)$ \\
\hline \multicolumn{3}{|l|}{ Housing tenure } \\
\hline Homeowner & 1 & 1 \\
\hline Renter & $5.07(4.92-5.22)$ & $2.28(2.20-2.36)$ \\
\hline Missing & $2.06(1.53-2.76)$ & $1.21(0.87-1.69)$ \\
\hline \multicolumn{3}{|l|}{ Province } \\
\hline Ontario & 1 & 1 \\
\hline Quebec & $0.97(0.93-1.01)$ & $0.69(0.66-0.72)$ \\
\hline Other & $1.00(0.97-1.03)$ & $1.09(1.05-1.13)$ \\
\hline
\end{tabular}

Finally, white households in Quebec were significantly protected against food insecurity compared with those in Ontario (Fig. 2f). However, living in Quebec was not protective for Black households, as both Black subgroups had nearly identical predicted probabilities. Black households in each provincial subgroup had significantly higher predicted probabilities compared with their white counterparts.

\section{Discussion}

Our analysis of population-representative data from 2005 to 2014 reveals that being racialized as Black is a potent predictor of household food insecurity. Even after adjusting for other socio-demographic characteristics, Black-respondent households experienced almost double

Fig. 2 Predicted probabilities of multivariable regression models with interactions with race. Within Fig. 2, figures a) to f) refer to predicted probabilities (PP, \%) that are derived from multivariable logistic regression models that have been adjusted for immigration status, household education, household composition, household income, imputed income, main source of household income, housing tenure, province, and CCHS cycle. Each graph refers to such an adjusted model in which there is an interaction between race and the indicated variable (e.g., a) race interacted with immigration) 
a) Race, Immigrant Status

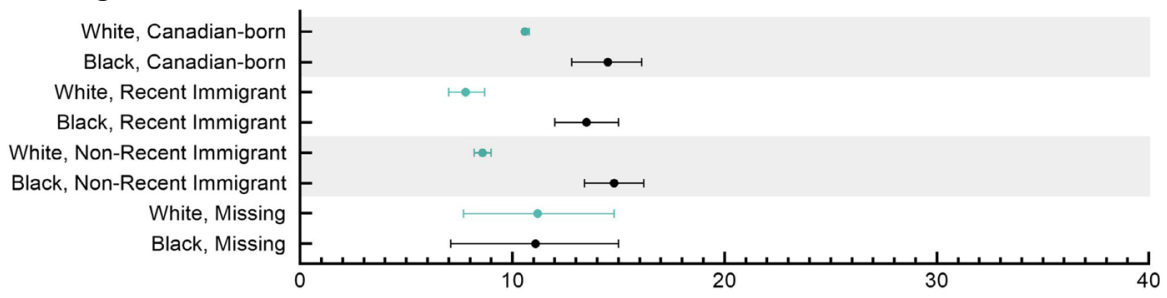

\begin{tabular}{|c|c|}
\hline $\mathbf{P P}^{*}(\%)$ & $\mathbf{9 5} \% \mathbf{C l}$ \\
\hline 10.6 & $10.5,10.8$ \\
\hline 14.5 & $12.8,16.1$ \\
\hline 7.8 & $7.0,8.7$ \\
\hline 13.5 & $12.0,15.0$ \\
\hline 8.6 & $8.2,9.0$ \\
\hline 14.8 & $13.4,16.2$ \\
\hline 11.2 & $7.7,14.8$ \\
\hline 11.1 & $7.1,15.0$ \\
\hline
\end{tabular}

\section{b) Race, Household Composition}

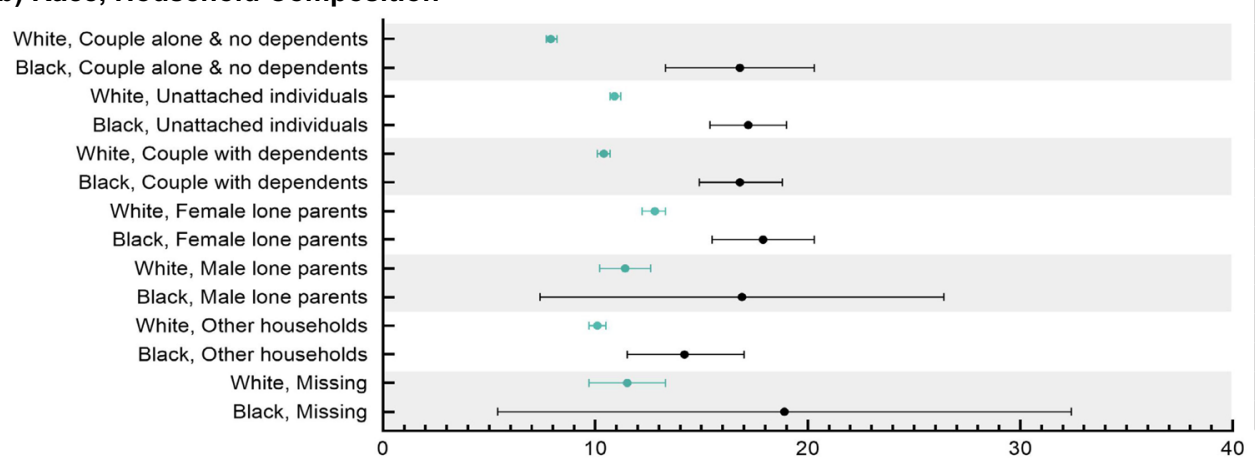

\section{c) Race, Main Source of Household Income}

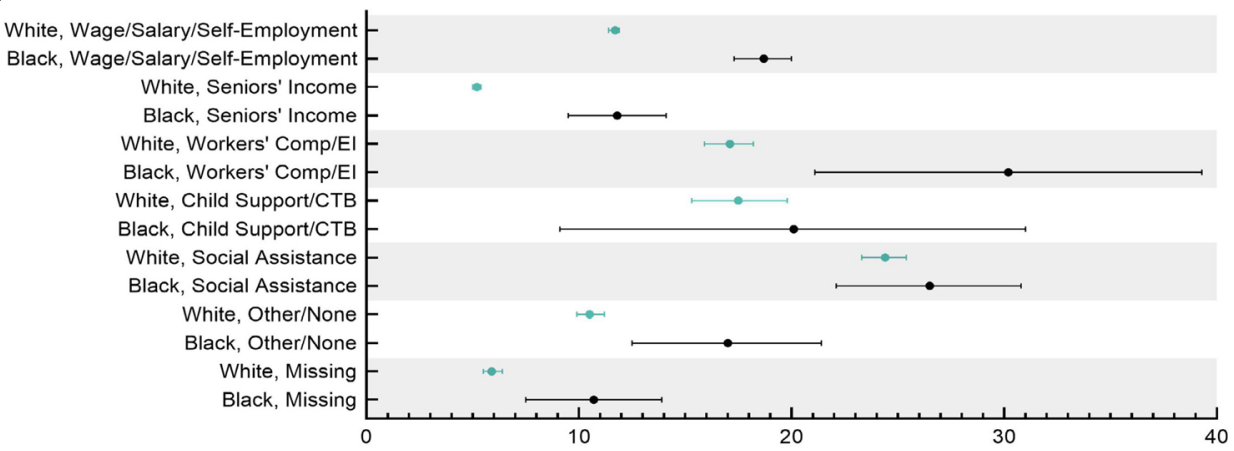

\begin{tabular}{|c|c|}
\hline $\mathbf{P P}(\mathbf{\%})$ & $\mathbf{9 5} \% \mathbf{C l}$ \\
\hline 7.9 & $7.7,8.2$ \\
\hline 16.8 & $13.3,20.3$ \\
\hline 10.9 & $10.7,11.2$ \\
\hline 17.2 & $15.4,19.0$ \\
\hline 10.4 & $10.1,10.7$ \\
\hline 16.8 & $14.9,18.8$ \\
\hline 12.8 & $12.2,13.3$ \\
\hline 17.9 & $15.5,20.3$ \\
\hline 11.4 & $10.2,12.6$ \\
\hline 16.9 & $7.4,26.4$ \\
\hline 10.1 & $9.7,10.5$ \\
\hline 14.2 & $11.5,17.0$ \\
\hline 11.5 & $9.7,13.3$ \\
\hline 18.9 & $5.4,32.4$ \\
\hline & \\
\hline
\end{tabular}

d) Race, Household Education
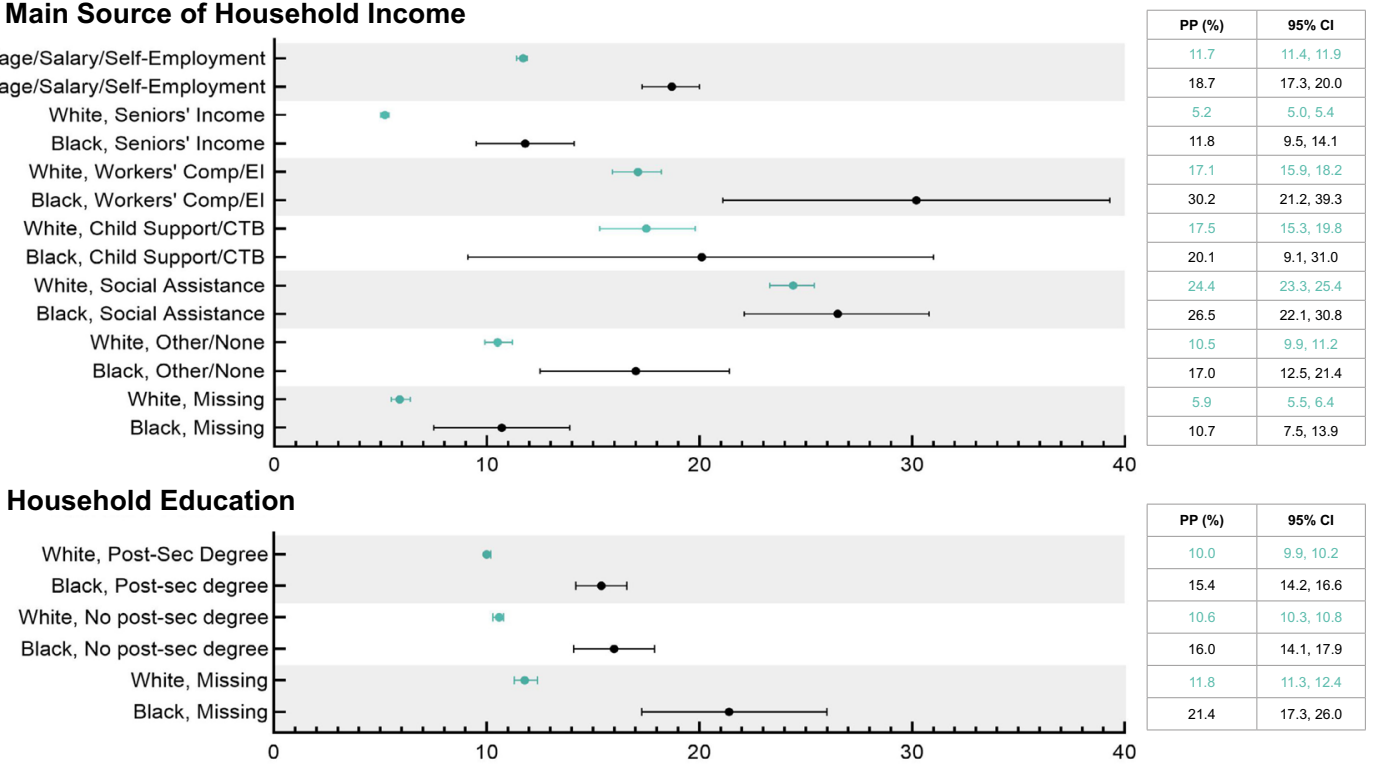

White, Post-Sec Degree

e) Race, Housing Tenure
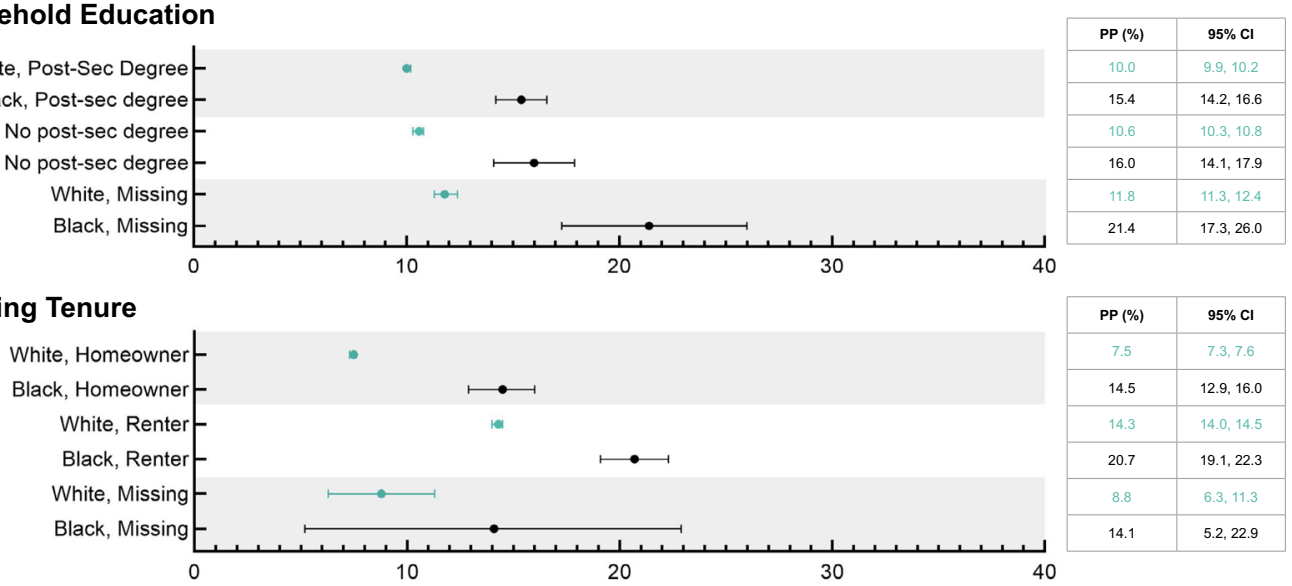

f) Race, Province
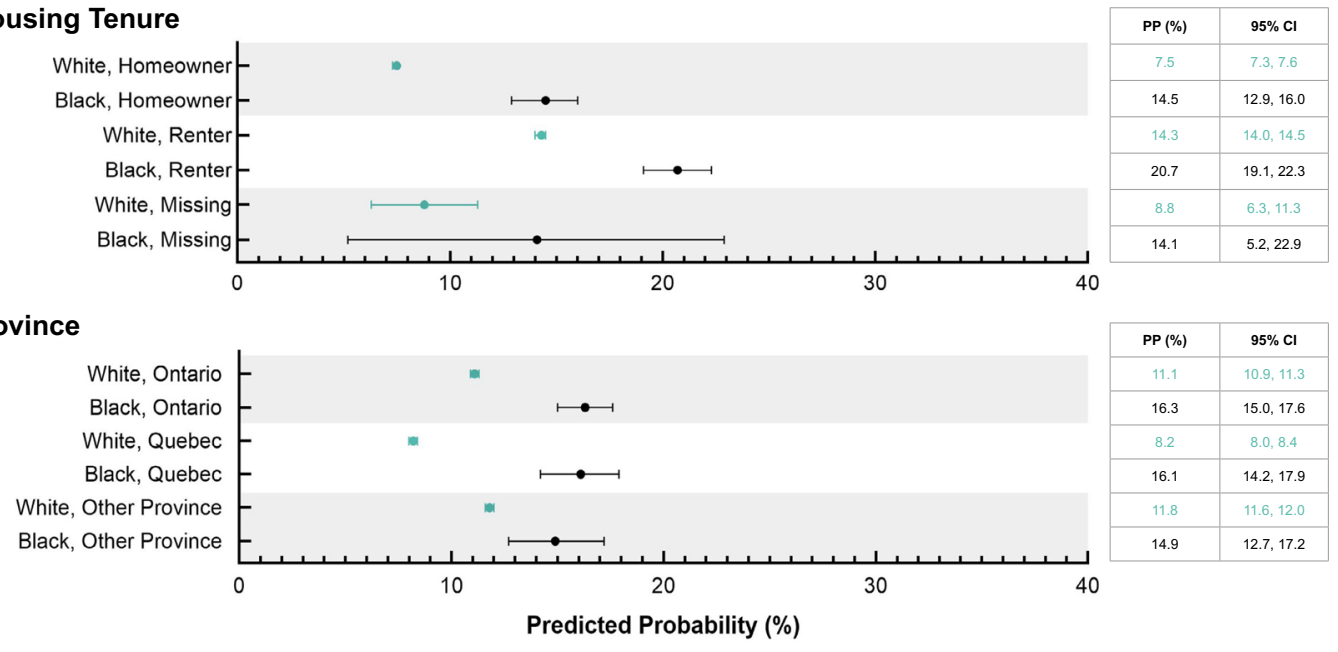
the odds of food insecurity of white-respondent households - an association as strong in magnitude as other commonly reported predictors of vulnerability, such as female lone-parenthood. Our findings demonstrate that the differential in household food insecurity between Black and white households exists on a national level, which is consistent with observations in two earlier, smaller Canadian studies (McIntyre et al., 2012a; Tarasuk et al., 2019b). Our predicted probabilities showed that characteristics traditionally denoting vulnerability to household food insecurity among the general population, which is predominantly white, do not shape Black vulnerability in the same way. Not only did all Black subgroups present with higher probabilities of food insecurity compared with their white counterparts, but there was relative homogeneity of risk among Black subgroups for immigration status, household composition, education, and province. Thus, being racialized as Black was a dominant predictor of elevated risk of household food insecurity.

The observed protective effect of immigration - in this case for white households - is consistent with other studies (Tarasuk et al., 2019a). By contrast, research on immigrants for other health outcomes finds that immigrant groups with a longer duration of residency in Canada exhibit worse cardiovascular risk factor profiles than recent immigrants, as part of the "healthy immigrant effect" (Chiu et al., 2012). In this study, we find that traditional understandings of the "healthy immigrant effect" in the broader immigrant and white population do not sufficiently explain risk of household food insecurity for the Black population. Black people, whether they have been in the country for less than 10 years or more, experience a similar level of vulnerability to household food insecurity. Furthermore, while living in Quebec was protective for white households, Black households in Quebec had the same probability of food insecurity as Black households in Ontario. That living in Quebec - as well as all other provinces-affords no discernible protection for the Black population suggests that race is uniquely shaping the vulnerability of this group.

Social epidemiologists and public health scholars have long argued that racial differences in economic outcomes are manifestations of structural racism and are powerful in shaping racial disparities in health (Lillie-Blanton \& Laveist, 1996; Williams \& Collins, 1995). Scholars in the USA have also established a potential relationship between racial discrimination and an elevated risk of food insecurity (Burke et al., 2018; Nam et al., 2015). In their study of African-American food-insecure households with children, Burke et al. (2018) found that, even after adjusting for socio-demographic factors, a one-unit increase in the frequency of lifetime racial discrimination was associated with a $5 \%$ increase in the odds of very low food insecurity. Odoms-Young (2018) argues that, in order to address racial disparities in food insecurity, interventions should target structural racism as well as class inequality. Given the potent role of race in our study, one prominent mechanism through which antiBlack racism may be manifesting is wealth inequityspecifically the accumulation of wealth among white households and the disenfranchisement of Black households. Numerous studies in Canada have noted the widening economic gap between racialized groups and white counterparts, as well as the particular economic disparities facing Black people in Canada (Attewell et al., 2010; Block \& Galabuzi, 2018; Livingstone \& Weinfeld, 2015). In addition to adjusting for income, our models included two markers of economic security: main source of household income and housing tenure. One plausible reason for why the predicted probability of food insecurity among Black households reliant on seniors' income was on par with white working households could be that Black seniors acquired fewer material assets during their working lives-possibly due to being streamlined into more precarious, low-wage work (Galabuzi, 2006; Krahn \& Lowe, 2002; Kunz et al., 2000)—compared with white counterparts, and that economic disadvantage followed them to old age. Similarly with housing tenure, Black homeowners may have similar vulnerability as white renters because homeownership may manifest differently for Black households (e.g., they may have homes worth less potentially due to racism in the housing market, or have houses with higher mortgage debt) (Fafard StGermain \& Tarasuk, 2020). While assets and debt differentials could not be examined with the data available in the CCHS, studies have shown that racialized neighbourhoods, particularly in Toronto, Montreal, and Vancouver, are overrepresented in experiencing household indebtedness (Walks, 2013). Scholars have long noted how racism operates at individual and structural levels, such that the metaphorical "tip" of the iceberg represents interpersonal acts of racism, but beneath the water's surface there are structural modes of racism that manifest through socio-economic systems (Gee et al., 2009; Jones, 2000). Structural racism may explain the racial differences in our findings, which show that Black subgroups that would in theory be protected from household food insecurity given their greater income security or material wealth (e.g., seniors' income, homeowners) are instead as vulnerable as the more disadvantaged white subgroup. Notably, we still see that Black homeowners fare better than Black renters, suggesting that material circumstances continue to shape disadvantage within racial groups.

Strengths of our study include the large, populationrepresentative sample, inclusion of a broad array of 
socio-demographic characteristics, use of a wellvalidated scale to assess household food insecurity, and multivariable models that examine both statistical interactions and severity of food insecurity. Several limitations remain in this study. First, our dataset from 2005 to 2014 reflects a dated sample. It is possible that studies of race with more recent cycles of the CCHS would yield different results. Second, given the crosssectional nature of the data, we cannot make inferences or gauge temporal relationships. Third, as with most studies on marginalized populations, the sample size for Black households was very small, which limits the precision of the estimates for this group and the possible analytic approaches. The small sample size therefore required a relatively creative and unconventional analytical approach. Finally, we were limited by the lack of breadth and specificity of variables offered by the CCHS. The CCHS contains no data on the stability of household income, subtypes of immigrants (e.g., refugees), the nature of employment of all household members, and wealth (i.e., assets, mortgages, other household debts). Our data source also did not provide any direct measure of participants' exposure to and experiences of racial discrimination, precluding any examination of discrimination that might manifest among the socio-demographic predictors we included in our models. In particular, given the disproportionately high probability of food insecurity among households reliant on Employment Insurance and workers' compensation, as well as the differential labour market experiences of Black and white populations, data on employment and economic indicators would be valuable for future studies.

\section{Conclusion}

Our results suggest that Black racialization is an overriding factor shaping household-level susceptibility to food insecurity in Canada. This highlights the importance of addressing structural anti-Black racism in endeavours to reduce, and ultimately eliminate, racial differences in household food insecurity. Our findings lay the foundation for future work to investigate economic disparities between Black and white populations in Canada. In the midst of a pandemic where racial inequities are coming to the fore, these findings further emphasize the need to centre a discussion of race, and indeed racism, in conversations and research about material deprivation and wealth inequities at the systemic and institutional levels. Furthermore, this study provides a rationale for long-overdue race-based data collection, as well as the oversampling of underrepresented groups, such as Black people, in Canadian surveys.

\section{Contributions to knowledge}

What does this study add to existing knowledge?

- A wealth of literature on Black-white disparities in household food insecurity exists in the USA, but a dedicated study on this topic has not existed for Canadian populations, despite indications of marked differences in prevalence by race. The pandemic has also further unveiled pre-existing racial inequities.

- This study, which dissects differences in vulnerability to household food insecurity between Black and white populations, directly fills this knowledge gap. We find that Black households had 1.88 greater odds of being food insecure than white households. Our findings contribute novel quantitative measures of racial disparities in household food insecurity to the literature.

What are the key implications for public health interventions, practice or policy?

- Public health interventions, practices, and policies on household food insecurity should consider the profound role of race as a social determinant of health, and decisions at the policy level ought to be informed by evidence on racial disparities. This is, of course, difficult to do in the absence of evidence, especially quantitative data that show just how disproportionately vulnerable Black households are to food insecurity.

- Findings from this study now provide decision-makers with the tools to craft policies that reduce household food insecurity by addressing anti-Black racism at institutional and structural levels.

\section{Appendix}

Table 3 Crude multinomial regression of race and severity of household food insecurity

\begin{tabular}{llll}
\hline \multirow{2}{*}{ Food insecurity } & \multicolumn{2}{l}{ Crude odds ratio $(95 \% \mathrm{CI})$} & \\
\cline { 2 - 4 } & Marginal & Moderate & Severe \\
\hline Race & & & \\
White & 1.00 & 1.00 & 1.00 \\
Black & $2.65(2.31-3.04)$ & $3.99(3.59-4.43)$ & $4.01(3.50-4.59)$ \\
\hline
\end{tabular}


Table 4 Adjusted multinomial regression of socio-demographic variables and severity of household food insecurity

\begin{tabular}{|c|c|c|c|}
\hline \multirow[t]{2}{*}{ Food insecurity } & \multicolumn{3}{|c|}{ Adjusted odds ratio (95\% CI) } \\
\hline & Marginal & Moderate & Severe \\
\hline \multicolumn{4}{|l|}{ Race } \\
\hline White & 1.00 & 1.00 & 1.00 \\
\hline Black & $1.62(1.39-1.90)$ & $2.02(1.77-2.30)$ & $1.99(1.68-2.37)$ \\
\hline \multicolumn{4}{|l|}{ CCHS cycle } \\
\hline 2005-2006 & 1.00 & 1.00 & 1.00 \\
\hline $2007-2008$ & $1.16(1.09-1.25)$ & $1.10(1.04-1.17)$ & $1.03(0.94-1.13)$ \\
\hline 2009-2010 & $0.99(0.92-1.07)$ & $1.10(1.02-1.18)$ & $1.13(1.02-1.25)$ \\
\hline 2011-2012 & $1.28(1.18-1.38)$ & $1.27(1.19-1.37)$ & $1.07(0.97-1.18)$ \\
\hline 2013-2014 & $1.25(1.15-1.36)$ & $1.22(1.13-1.31)$ & $1.14(1.02-1.27)$ \\
\hline \multicolumn{4}{|l|}{ Immigration status } \\
\hline Canadian-born & 1.00 & 1.00 & 1.00 \\
\hline Recent immigrant ( $0-10$ years $)$ & $0.76(0.64-0.91)$ & $0.74(0.63-0.86)$ & $0.53(0.43-0.67)$ \\
\hline Non-recent immigrant (11+ years) & $0.82(0.74-0.90)$ & $0.77(0.71-0.84)$ & $0.73(0.64-0.83)$ \\
\hline Missing & $0.83(0.54-1.27)$ & $0.95(0.56-1.60)$ & $0.56(0.25-1.24)$ \\
\hline \multicolumn{4}{|l|}{ Highest level of household education } \\
\hline Post-secondary degree & 1.00 & 1.00 & 1.00 \\
\hline No post-secondary degree & $1.07(1.01-1.13)$ & $1.12(1.06-1.18)$ & $1.01(0.94-1.09)$ \\
\hline Missing & $1.23(1.11-1.37)$ & $1.34(1.21-1.49)$ & $1.30(1.12-1.51)$ \\
\hline \multicolumn{4}{|l|}{ Household composition } \\
\hline Couple, no children & 1.00 & 1.00 & 1.00 \\
\hline Unattached & $1.32(1.23-1.42)$ & $1.42(1.33-1.52)$ & $2.23(2.00-2.48)$ \\
\hline Couple with children & $1.50(1.39-1.63)$ & $1.43(1.33-1.55)$ & $1.17(1.02-1.34)$ \\
\hline Female lone parent & $1.90(1.69-2.12)$ & $1.81(1.64-1.99)$ & $1.88(1.63-2.17)$ \\
\hline Male lone parent & $2.01(1.54-2.63)$ & $1.35(1.08-1.68)$ & $1.53(1.08-2.16)$ \\
\hline Other household types & $1.39(1.26-1.54)$ & $1.30(1.19-1.43)$ & $1.44(1.23-1.69)$ \\
\hline Missing & $1.47(1.07-2.03)$ & $1.71(1.28-2.28)$ & $1.81(1.00-3.25)$ \\
\hline Household income & $0.97(0.97-0.97)$ & $0.96(0.96-0.96)$ & $0.94(0.94-0.95)$ \\
\hline \multicolumn{4}{|l|}{ Imputed income } \\
\hline Reported & 1.00 & 1 & 1.00 \\
\hline Imputed & $0.82(0.77-0.87)$ & $0.72(0.68-0.77)$ & $0.58(0.53-0.63)$ \\
\hline \multicolumn{4}{|l|}{ Main household income source } \\
\hline Wage/salary or self-employed & 1.00 & 1.00 & 1.00 \\
\hline Seniors' income (pensions, Old Age Security, dividends) & $0.46(0.42-0.49)$ & $0.37(0.34-0.39)$ & $0.29(0.26-0.32)$ \\
\hline Workers' compensation or employment insurance & $1.38(1.17-1.63)$ & $1.64(1.43-1.88)$ & $2.23(1.90-2.62)$ \\
\hline Child support or child tax benefit & $1.42(1.00-2.03)$ & $1.62(1.26-2.08)$ & $1.93(1.46-2.54)$ \\
\hline Social assistance & $1.68(1.46-1.92)$ & $2.41(2.19-2.66)$ & $3.92(3.52-4.37)$ \\
\hline Other or none & $0.87(0.75-1.01)$ & $0.84(0.75-0.96)$ & $0.84(0.72-0.97)$ \\
\hline Missing & $0.51(0.45-0.59)$ & $0.44(0.38-0.50)$ & $0.30(0.25-0.37)$ \\
\hline \multicolumn{4}{|l|}{ Housing tenure } \\
\hline Homeowner & 1.00 & 1.00 & 1.00 \\
\hline Renter & $1.88(1.77-1.99)$ & $2.42(2.30-2.55)$ & $2.87(2.66-3.10)$ \\
\hline Missing & $1.30(0.83-2.04)$ & $1.30(0.83-2.04)$ & $0.75(0.35-1.59)$ \\
\hline \multicolumn{4}{|l|}{ Province } \\
\hline Ontario & 1.00 & 1.00 & 1.00 \\
\hline Quebec & $0.90(0.84-0.97)$ & $0.64(0.60-0.68)$ & $0.49(0.45-0.54)$ \\
\hline Other & $1.18(1.11-1.25)$ & $1.07(1.01-1.12)$ & $1.02(0.95-1.10)$ \\
\hline
\end{tabular}


Table 5 Logistic regression models featuring interactions between race and six socio-demographic variables

\begin{tabular}{|c|c|c|c|}
\hline & Odds ratio & 95\% CI (lower) & $95 \%$ CI (upper) \\
\hline \multicolumn{4}{|l|}{ Interaction between race and immigration } \\
\hline \multicolumn{4}{|l|}{ Race (REF: White) } \\
\hline \multicolumn{4}{|l|}{ Immigration (REF: Canadian-born) } \\
\hline Recent immigrant $(0-10$ years $)$ & 0.66 & 0.57 & 0.77 \\
\hline Non-recent immigrant ( $11+$ years $)$ & 0.75 & 0.70 & 0.80 \\
\hline Missing & 1.08 & 0.69 & 1.68 \\
\hline \multicolumn{4}{|c|}{ Race*Immigration (REF: White Canadian-born) } \\
\hline Black, Recent immigrant $(0-10$ years $)$ & 1.36 & 1.03 & 1.79 \\
\hline Black, Non-recent immigrant (11+ years) & 1.38 & 1.10 & 1.75 \\
\hline Black, Missing immigration status & 0.63 & 0.32 & 1.26 \\
\hline \multicolumn{4}{|l|}{ Education (REF: Post-sec degree) } \\
\hline No post-sec degree & 1.07 & 1.03 & 1.11 \\
\hline Missing & 1.29 & 1.20 & 1.39 \\
\hline \multicolumn{4}{|c|}{ Household composition (REF: Couple alone, no children) } \\
\hline Unattached & 1.51 & 1.44 & 1.58 \\
\hline Couple with children & 1.41 & 1.34 & 1.49 \\
\hline Female lone parent & 1.83 & 1.70 & 1.97 \\
\hline Male lone parent & 1.59 & 1.37 & 1.84 \\
\hline Other household types & 1.35 & 1.27 & 1.44 \\
\hline Missing & 1.63 & 1.29 & 2.05 \\
\hline Household income & 0.96 & 0.96 & 0.96 \\
\hline Imputed income (REF: reported) & 0.72 & 0.70 & 0.75 \\
\hline \multicolumn{4}{|c|}{ Main household income source (REF: Wage/salary/self-employment) } \\
\hline Pensions/Old Age Security/dividends & 0.38 & 0.36 & 0.40 \\
\hline Workers' comp and EI & 1.70 & 1.54 & 1.87 \\
\hline Child support and child tax benefit & 1.66 & 1.36 & 2.04 \\
\hline Social assistance & 2.80 & 2.60 & 3.02 \\
\hline Other/none & 0.87 & 0.80 & 0.95 \\
\hline Missing & 0.44 & 0.40 & 0.48 \\
\hline \multicolumn{4}{|l|}{ Rent (REF: Homeowner) } \\
\hline Renter & 2.27 & 2.19 & 2.36 \\
\hline Missing & 1.22 & 0.88 & 1.69 \\
\hline \multicolumn{4}{|l|}{ Province (REF: Ontario) } \\
\hline Quebec & 0.68 & 0.65 & 0.71 \\
\hline Missing & 1.09 & 1.05 & 1.13 \\
\hline Cycle (REF: 2005-2006) & & & \\
\hline $2007-2008$ & 1.11 & 1.06 & 1.16 \\
\hline $2009-2010$ & 1.07 & 1.02 & 1.12 \\
\hline $2011-2012$ & 1.23 & 1.17 & 1.30 \\
\hline 2013-2014 & 1.21 & 1.15 & 1.28 \\
\hline Constant & 0.35 & 0.32 & 0.38 \\
\hline Interaction between race and income sour & & & \\
\hline Race (REF: White) & & & \\
\hline Black & 1.93 & 1.72 & 2.16 \\
\hline Main income source (REF: Wage/salary/s & & & \\
\hline Pensions/Old Age Security/dividends & 0.38 & 0.36 & 0.39 \\
\hline Workers' comp and EI & 1.68 & 1.52 & 1.86 \\
\hline Child support and child tax benefit & 1.75 & 1.45 & 2.12 \\
\hline Social assistance & 2.92 & 2.71 & 3.15 \\
\hline Other/none & 0.87 & 0.80 & 0.95 \\
\hline Missing & 0.43 & 0.40 & 0.48 \\
\hline Race*Income Source (REF: White, Wage & & & \\
\hline Black, Pensions/OAS/dividends & 1.40 & 1.06 & 1.85 \\
\hline Black, Workers' comp/EI & 1.32 & 0.74 & 2.36 \\
\hline Black, Child support/CTB & 0.63 & 0.27 & 1.51 \\
\hline Black, Social assistance & 0.60 & 0.44 & 0.82 \\
\hline Black, Other/none & 0.99 & 0.66 & 1.48 \\
\hline Black, Missing & 1.06 & 0.70 & 1.59 \\
\hline Education (REF: Post-sec degree) & & & \\
\hline No post-sec degree & 1.07 & 1.03 & 1.12 \\
\hline Missing & 1.29 & 1.20 & 1.38 \\
\hline Household composition (REF: Couple alo & & & \\
\hline Unattached & 1.51 & 1.44 & 1.58 \\
\hline Couple with children & 1.41 & 1.34 & 1.49 \\
\hline Female lone parent & 1.84 & 1.71 & 1.97 \\
\hline Male lone parent & 1.59 & 1.37 & 1.85 \\
\hline Other household types & 1.35 & 1.26 & 1.44 \\
\hline Missing & 1.63 & 1.30 & 2.05 \\
\hline Household income & 0.96 & 0.96 & 0.96 \\
\hline Imputed income (REF: reported) & 0.72 & 0.70 & 0.75 \\
\hline Immigration (REF: Canadian-born) & & & \\
\hline Recent immigrant $(0-10$ years $)$ & 0.71 & 0.63 & 0.80 \\
\hline Non-recent immigrant ( $11+$ years $)$ & 0.77 & 0.73 & 0.82 \\
\hline Missing & 0.84 & 0.59 & 1.20 \\
\hline Rent (REF: Homeowner) & & & \\
\hline Renter & 2.27 & 2.19 & 2.35 \\
\hline
\end{tabular}


Table 5 (continued)

\begin{tabular}{|c|c|c|c|}
\hline & Odds ratio & 95\% CI (lower) & $95 \% \mathrm{CI}$ (upper) \\
\hline Missing & 1.21 & 0.87 & 1.68 \\
\hline \multicolumn{4}{|l|}{ Province (REF: Ontario) } \\
\hline Quebec & 0.68 & 0.65 & 0.71 \\
\hline Missing & 1.09 & 1.05 & 1.13 \\
\hline \multicolumn{4}{|l|}{ Cycle (REF: 2005-2006) } \\
\hline $2007-2008$ & 1.11 & 1.06 & 1.16 \\
\hline 2009-2010 & 1.07 & 1.02 & 1.12 \\
\hline $2011-2012$ & 1.23 & 1.17 & 1.30 \\
\hline 2013-2014 & 1.21 & 1.15 & 1.28 \\
\hline Constant & 0.34 & 0.32 & 0.37 \\
\hline \multicolumn{4}{|l|}{ Interaction between race and household composition } \\
\hline \multicolumn{4}{|l|}{ Race (REF: White) } \\
\hline \multirow{2}{*}{\multicolumn{4}{|c|}{ Household composition (REF: Couple alone, no children) }} \\
\hline & & & \\
\hline Unattached individuals & 1.53 & 1.45 & 1.60 \\
\hline Couple with children & 1.42 & 1.35 & 1.50 \\
\hline Female lone parents & 1.88 & 1.75 & 2.02 \\
\hline Male lone parents & 1.61 & 1.39 & 1.87 \\
\hline Other household types, and kids 18 years and older & 1.38 & 1.29 & 1.47 \\
\hline Missing & 1.63 & 1.30 & 2.03 \\
\hline \multicolumn{4}{|c|}{ Race*Household composition (REF: White, Couple alone w/ no children) } \\
\hline Black, Unattached individuals & 0.68 & 0.48 & 0.97 \\
\hline Black, Couple with children & 0.70 & 0.49 & 1.01 \\
\hline Black, Female lone parents & 0.58 & 0.40 & 0.85 \\
\hline Black, Male lone parents & 0.62 & 0.25 & 1.56 \\
\hline Black, Other household types & 0.57 & 0.37 & 0.87 \\
\hline \multirow{2}{*}{\multicolumn{4}{|c|}{ Education (REF: Post-sec degree) }} \\
\hline & & & \\
\hline No post-sec degree & 1.07 & 1.03 & 1.12 \\
\hline Missing & 1.29 & 1.20 & 1.38 \\
\hline \multicolumn{4}{|l|}{ Main income source (REF: Wage/salary/self-employment) } \\
\hline Pensions/Old Age Security/dividends & 0.38 & 0.36 & 0.40 \\
\hline Workers' comp and EI & 1.71 & 1.55 & 1.88 \\
\hline Child support and child tax benefit & 1.66 & 1.36 & 2.03 \\
\hline Social assistance & 2.80 & 2.60 & 3.02 \\
\hline Other/none & 0.87 & 0.80 & 0.95 \\
\hline Missing & 0.44 & 0.40 & 0.48 \\
\hline Household income & 0.96 & 0.96 & 0.96 \\
\hline \multirow{2}{*}{\multicolumn{4}{|c|}{ Immigration (REF: Canadian-born) }} \\
\hline & & & \\
\hline Recent immigrant $(0-10$ years $)$ & 0.70 & 0.62 & 0.78 \\
\hline Non-recent immigrant (11+ years) & 0.77 & 0.73 & 0.82 \\
\hline Missing & 0.82 & 0.57 & 1.17 \\
\hline Rent (REF: Homeowner) & & & \\
\hline Renter & 2.27 & 2.19 & 2.35 \\
\hline Missing & 1.21 & 0.87 & 1.68 \\
\hline Province (REF: Ontario) & & & \\
\hline Quebec & 0.68 & 0.65 & 0.71 \\
\hline Missing & 1.09 & 1.05 & 1.13 \\
\hline Cycle (REF: 2005-2006) & & & \\
\hline $2007-2008$ & 1.11 & 1.06 & 1.16 \\
\hline 2009-2010 & 1.07 & 1.01 & 1.12 \\
\hline $2011-2012$ & 1.23 & 1.17 & 1.30 \\
\hline 2013-2014 & 1.21 & 1.15 & 1.28 \\
\hline Constant & 0.34 & 0.31 & 0.37 \\
\hline Interaction between race and rent & & & \\
\hline Race (REF: White) & & & \\
\hline Black & 2.35 & 2.03 & 2.73 \\
\hline Rent (REF: Homeowner) & & & \\
\hline Renter & 2.30 & 2.22 & 2.39 \\
\hline Missing & 1.22 & 0.86 & 1.74 \\
\hline Race*Rent (REF: White, Homeowner) & & & \\
\hline Black, Renter & 0.73 & 0.61 & 0.88 \\
\hline Black, Missing & 0.78 & 0.30 & 2.02 \\
\hline Education (REF: Post-sec degree) & & & \\
\hline No post-sec degree & 1.07 & 1.03 & 1.12 \\
\hline Missing & 1.29 & 1.20 & 1.38 \\
\hline Main income source (REF: Wage/salary/self-employ & & & \\
\hline Pensions/Old Age Security/dividends & 0.38 & 0.36 & 0.39 \\
\hline Workers' comp and EI & 1.71 & 1.55 & 1.88 \\
\hline Child support and child tax benefit & 1.67 & 1.37 & 2.05 \\
\hline Social assistance & 2.80 & 2.60 & 3.02 \\
\hline Other/none & 0.87 & 0.80 & 0.95 \\
\hline Missing & 0.44 & 0.40 & 0.48 \\
\hline Household income & 0.96 & 0.96 & 0.96 \\
\hline Imputed income (REF: reported) & 0.72 & 0.70 & 0.75 \\
\hline
\end{tabular}


Table 5 (continued)

\begin{tabular}{|c|c|c|c|}
\hline & Odds ratio & 95\% CI (lower) & $95 \%$ CI (upper) \\
\hline Recent immigrant ( $0-10$ years $)$ & 0.72 & 0.64 & 0.80 \\
\hline Non-recent immigrant $(11+$ years $)$ & 0.78 & 0.73 & 0.83 \\
\hline Missing & 0.84 & 0.59 & 1.19 \\
\hline \multicolumn{4}{|l|}{ Household composition (REF: Couple alone, no children) } \\
\hline Unattached individuals & 1.51 & 1.44 & 1.58 \\
\hline Couple with children & 1.41 & 1.34 & 1.49 \\
\hline Female lone parents & 1.83 & 1.70 & 1.96 \\
\hline Male lone parents & 1.59 & 1.37 & 1.85 \\
\hline Other household types, and kids 18 years and older & 1.35 & 1.26 & 1.44 \\
\hline Missing & 1.62 & 1.29 & 2.04 \\
\hline \multicolumn{4}{|l|}{ Province (REF: Ontario) } \\
\hline Quebec & 0.68 & 0.65 & 0.71 \\
\hline Missing & 1.09 & 1.05 & 1.13 \\
\hline \multicolumn{4}{|l|}{ Cycle (REF: 2005-2006) } \\
\hline $2007-2008$ & 1.11 & 1.06 & 1.16 \\
\hline 2009-2010 & 1.07 & 1.02 & 1.12 \\
\hline 2011-2012 & 1.23 & 1.17 & 1.30 \\
\hline 2013-2014 & 1.21 & 1.15 & 1.28 \\
\hline Constant & 0.34 & 0.31 & 0.37 \\
\hline \multicolumn{4}{|l|}{ Interaction between race and province } \\
\hline \multicolumn{4}{|l|}{ Race (REF: White) } \\
\hline Black & 1.76 & 1.55 & 1.99 \\
\hline Province (REF: Ontario) & & & \\
\hline Quebec & 0.67 & 0.64 & 0.70 \\
\hline Other provinces & 1.09 & 1.05 & 1.13 \\
\hline \multicolumn{4}{|l|}{ Race*Province (REF: Black, Ontario) } \\
\hline Black, Quebec & 1.46 & 1.18 & 1.81 \\
\hline Black, Other provinces & 0.80 & 0.62 & 1.03 \\
\hline \multicolumn{4}{|l|}{ Education (REF: Post-sec degree) } \\
\hline No post-sec degree & 1.08 & 1.04 & 1.12 \\
\hline \multirow{2}{*}{\multicolumn{4}{|c|}{ Main income source (REF: Wage/salary/self-employment) }} \\
\hline & & & \\
\hline Pensions/Old Age Security/dividends & 0.38 & 0.36 & 0.39 \\
\hline Workers' comp and EI & 1.71 & 1.55 & 1.88 \\
\hline Child support and child tax benefit & 1.67 & 1.37 & 2.04 \\
\hline Social assistance & 2.80 & 2.60 & 3.02 \\
\hline Other/none & 0.87 & 0.79 & 0.94 \\
\hline Missing & 0.44 & 0.40 & 0.48 \\
\hline Household income & 0.96 & 0.96 & 0.96 \\
\hline Imputed income (REF: reported) & 0.72 & 0.69 & 0.75 \\
\hline Immigration (REF: Canadian-born) & & & \\
\hline Recent immigrant ( $0-10$ years $)$ & 0.70 & 0.62 & 0.78 \\
\hline Non-recent immigrant ( $11+$ years $)$ & 0.77 & 0.72 & 0.82 \\
\hline Missing & 0.83 & 0.58 & 1.19 \\
\hline Household composition (REF: Couple alone, no chil & & & \\
\hline Unattached individuals & 1.51 & 1.44 & 1.58 \\
\hline Couple with children & 1.41 & 1.34 & 1.49 \\
\hline Female lone parents & 1.83 & 1.70 & 1.96 \\
\hline Male lone parents & 1.59 & 1.37 & 1.85 \\
\hline Other household types, and kids 18 years and older & 1.35 & 1.26 & 1.44 \\
\hline Missing & 1.62 & 1.29 & 2.04 \\
\hline Rent (REF: Homeowner) & & & \\
\hline Renter & 2.27 & 2.19 & 2.36 \\
\hline Missing & 1.21 & 0.87 & 1.68 \\
\hline Cycle (REF: 2005-2006) & & & \\
\hline $2007-2008$ & 1.11 & 1.06 & 1.16 \\
\hline 2009-2010 & 1.07 & 1.01 & 1.12 \\
\hline 2011-2012 & 1.23 & 1.17 & 1.29 \\
\hline 2013-2014 & 1.21 & 1.15 & 1.28 \\
\hline Constant & 0.35 & 0.32 & 0.38 \\
\hline Interaction between race and education & & & \\
\hline Race (REF: White) & & & \\
\hline Black & 1.84 & 1.63 & 2.08 \\
\hline Household education (REF: Post-sec degree) & & & \\
\hline No post-sec degree & 1.07 & 1.03 & 1.12 \\
\hline Missing & 1.26 & 1.17 & 1.35 \\
\hline Race*Household education (REF: White, Post-sec d & & & \\
\hline Black, No post-sec degree & 0.99 & 0.80 & 1.22 \\
\hline Black, Missing & 1.34 & 0.95 & 1.88 \\
\hline Immigration (REF: Canadian-born) & & & \\
\hline Recent immigrant ( $0-10$ years $)$ & 0.70 & 0.62 & 0.79 \\
\hline Non-recent immigrant ( $11+$ years $)$ & 0.78 & 0.73 & 0.83 \\
\hline Missing & 0.83 & 0.58 & 1.19 \\
\hline Household composition (REF: Couple alone, no chil & & & \\
\hline Unattached individuals & 1.51 & 1.44 & 1.58 \\
\hline Couple with children & 1.41 & 1.34 & 1.49 \\
\hline Female lone parents & 1.83 & 1.70 & 1.96 \\
\hline
\end{tabular}


Table 5 (continued)

\begin{tabular}{|c|c|c|c|}
\hline & Odds ratio & 95\% CI (lower) & $95 \%$ CI (upper) \\
\hline Male lone parents & 1.59 & 1.36 & 1.84 \\
\hline Other household types, and kids 18 years and older & 1.35 & 1.26 & 1.44 \\
\hline Missing & 1.62 & 1.29 & 2.05 \\
\hline Household income & 0.96 & 0.96 & 0.96 \\
\hline Imputed income (REF: reported) & 0.72 & 0.70 & 0.75 \\
\hline \multicolumn{4}{|l|}{ Main income source (REF: Wage/salary/self-employment) } \\
\hline Pensions/Old Age Security/dividends & 0.38 & 0.36 & 0.39 \\
\hline Workers' comp and EI & 1.70 & 1.54 & 1.88 \\
\hline Child support and child tax benefit & 1.67 & 1.37 & 2.05 \\
\hline Social assistance & 2.80 & 2.60 & 3.02 \\
\hline Other/none & 0.87 & 0.80 & 0.95 \\
\hline Missing & 0.44 & 0.40 & 0.48 \\
\hline \multicolumn{4}{|l|}{ Rent (REF: Homeowner) } \\
\hline Renter & 2.27 & 2.19 & 2.36 \\
\hline Missing & 1.21 & 0.87 & 1.68 \\
\hline \multicolumn{4}{|l|}{ Province (REF: Ontario) } \\
\hline Quebec & 0.68 & 0.65 & 0.71 \\
\hline Missing & 1.09 & 1.05 & 1.13 \\
\hline \multicolumn{4}{|l|}{ Cycle (REF: 2005-2006) } \\
\hline $2007-2008$ & 1.11 & 1.06 & 1.16 \\
\hline 2009-2010 & 1.07 & 1.02 & 1.12 \\
\hline $2011-2012$ & 1.23 & 1.17 & 1.30 \\
\hline 2013-2014 & 1.21 & 1.15 & 1.28 \\
\hline Constant & 0.35 & 0.32 & 0.38 \\
\hline
\end{tabular}

Acknowledgements The authors are indebted to Andree-Anne Fafard StGermain for her assistance with this analysis, and to FoodShare Toronto for their support in linking these findings to community needs and programs.

Code availability Code from Stata is available upon request.

Author contributions SD cleaned the data and analyzed the outputs regarding Black-white racial disparities in household food insecurity, based on multiple statistical models. Both SD and VT collectively and iteratively interpreted the outputs and models for further analysis. Both authors read, edited, and approved the final manuscript.

Funding This study was supported by Canadian Institutes of Health Research, grant PJT 153260.

Data availability The analyses presented in this paper were conducted at Statistics Canada's Toronto Research Data Centre at the University of Toronto, which is part of the Canadian Research Data Centre Network. The authors thank the Canadian Research Data Centre Network for facilitating their access to the Canadian Community Health Survey.

The data that support the findings of this study are available from Statistics Canada's Toronto Research Data Centre, but restrictions apply to the availability of these data, which were used under license for the current study, and so are not publicly available. Data are however available from the authors upon reasonable request and with permission of the Canadian Research Data Centre Network.

\section{Declarations}

Ethics approval and consent to participate We obtained ethics approval for this study from the University of Toronto Health Sciences Research Ethics Board.

Consent for publication The authors agree to the publication.

Conflict of interest The authors declare no competing interests.

\section{References}

Attewell, P., Kasinitz, P., \& Dunn, K. (2010). Black Canadians and Black Americans: Racial income inequality in comparative perspective. Ethnic and Racial Studies, 33(3), 473-495. https://doi.org/10. 1080/01419870903085883.

Block, S., \& Galabuzi, G. (2018). Persistent inequality: Ontario's colourcoded labour market. Ottawa: Canadian Centre for Policy Alternatives.

Burke, M. P., Jones, S. J., Frongillo, E. A., Fram, M. S., Blake, C. E., \& Freedman, D. A. (2018). Severity of household food insecurity and lifetime racial discrimination among African-American households in South Carolina. Ethn health, 23(3), 276-292. https://doi.org/10. 1080/13557858.2016.1263286.

Chiu, M., Austin, P., Manuel, D., \& Tu, J. (2012). Cardiovascular risk factor profiles of recent immigrants vs long-term residents of Ontario: A multi-ethnic study. Canadian Journal of Cardiology, 28(1), 20-26. https://doi.org/10.1016/j.cjca.2011.06.002.

Coleman-Jensen, A., Rabbitt, M., Gregory, C., \& Singh, A. (2019). Household food security in the United States in 2018. Economic Research Report: U.S. Department of Agriculture, Economic Research Service.

Fafard St-Germain, A. A., \& Tarasuk, V. (2020). Homeownership status and risk of food insecurity: Examining the role of housing debt, housing expenditure and housing asset using a cross-sectional population-based survey of Canadian households. International Journal for Equity in Health, 19(5), 1-12. https://doi.org/10.1186/s12939019-1114-z.

Galabuzi, G. E. (2006). Canada's economic apartheid: The social exclusion of racialized groups in the new century. Canadian Scholars' Press.

Gee, G. C., Ro, A., Shariff-Marco, S., \& Chae, D. (2009). Racial discrimination and health among Asian Americans: Evidence, assessment, and directions for future research. Epidemiol Rev, 31, 130-51. https://doi.org/10.1093/epirev/mxp009.

Government of Canada. (2020). Determining food security status. https:// www.canada.ca/en/health-canada/services/food-nutrition/foodnutrition-surveillance/health-nutrition-surveys/canadiancommunity-health-survey-cchs/household-food-insecurity-canada- 
overview/determining-food-security-status-food-nutritionsurveillance-health-canada.html. Accessed 25 Aug 2020.

Jessiman-Perreault, G., \& McIntyre, L. (2017). The household food insecurity gradient and potential reductions in adverse population mental health outcomes in Canadian adults. SSM -Population Health, 3, $464-472$.

Jones, C. (2000). Levels of racism: A theoretic framework and a gardener's tale. American Journal of Public Health, 90, 1212-1215. https://doi.org/10.2105/ajph.90.8.1212.

Krahn, H. J., \& Lowe, G. S. (2002). Work Industry and Canadian Society (4th ed.). Nelson.

Kunz, J., Milan, A., \& Schetagne, S. (2000). Unequal access: A Canadian profile of racial differences in education, employment and income. Canadian Race Relations. The Foundation.

Lillie-Blanton, M., \& Laveist, T. (1996). Race/ethnicity, the social environment, and health. Social Science \& Medicine, 43(1), 83-91. https://doi.org/10.1016/0277-9536(95)00337-1.

Livingstone, A., \& Weinfeld, M. (2015). Black families and socioeconomic inequality in Canada. Canadian Ethnic Studies, 47(3), 1-23. https://doi.org/10.1353/ces.2015.0026.

McIntyre, L., Bartoo, A., \& Emery, J. (2012a). When working is not enough: food insecurity in the Canadian labour force. Public Health Nutrition, 17(1), 49-57.

McIntyre, L., Williams, J., Lavorato, D., \& Patten, S. (2012b). Depression and suicide ideation in late adolescence and early adulthood are an outcome of child hunger. Journal of Affective Disorders, 150(1), 123-129. https://doi.org/10.1016/j.jad.2012.11. 029.

Men, F., Gundersen, C., Urquia, M., \& Tarasuk, V. (2020a). Association between household food insecurity and mortality in Canada: A population-based retrospective cohort study. Canadian Medical Association Journal, 192(3), E53-E60. https://doi.org/10.1503/ cmaj.190385.

Men, F., Gundersen, C., Urquia, M. L., \& Tarasuk, V. (2020b). Food insecurity is associated with higher health care use and costs among Canadian adults. Health Affairs, 39(8), 1377-1385. https://doi.org/ 10.1377/hlthaff.2019.01637.

Nam, Y., Huang, J., Heflin, C., \& Sherraden, M. (2015). Racial and ethnic disparities in food insufficiency: Evidence from a statewide probability sample. Journal of the Society for Social Work and Research, 6(2), 201-228. https://doi.org/10.1086/681574.

Odoms-Young, A. (2018). Examining the impact of structural racism on food insecurity: Implications for addressing racial/ethnic disparities. Family \& Community Health, 41(Suppl 2), S3-S6. https://doi.org/ 10.1097/FCH.0000000000000183.

Persoskie, A., \& Ferrer, R. A. (2017). A most odd ratio: Interpreting and describing odds ratios. American Journal of Preventive Medicine, 52(2), 224-228. https://doi.org/10.1016/j.amepre.2016.07.030.

Statistics Canada. (2016). Diversity of the Black population in Canada: An overview. https://www150.statcan.gc.ca/n1/pub/89-657-x/89657-x2019002-eng.htm.

Statistics Canada. (2017). Visible Minority and Population Group Reference Guide, Census of Population, 2016. https://www12. statcan.gc.ca/census-recensement/2016/ref/guides/006/98-500x2016006-eng.cfm. Accessed 23 Dec 2019.

Statistics Canada. (2020). Food insecurity during the COVID-19 pandemic, May 2020. Statistics Canada.

Tarasuk, V., \& Mitchell, A. (2020). Household food insecurity in Canada, 2017-18. Toronto: Research to identify policy options to reduce food insecurity(PROOF).

Tarasuk, V., Fafard St-Germain, A.-A., \& Mitchell, A. (2019a). Geographic and socio-demographic predictors of household food insecurity in Canada, 2011-12. BMC Public Health, 19(1), 12. https://doi.org/10.1186/s12889-018-6344-2.

Tarasuk, V., Li, N., Dachner, N., \& Mitchell, A. (2019b). Household food insecurity in Ontario during a period of poverty reduction, 20052014. Canadian Public Policy, 45(1), 93-104. https://doi.org/10. 3138/cpp.2018-054.

Walks, A. (2013). Mapping the urban debtscape: The geography of household debt in Canadian cities. Urban Geography, 34(2), 153187. https://doi.org/10.1080/02723638.2013.778647.

Williams, D. R., \& Collins, C. (1995). US socioeconomic and racial differences in health: Patterns and explanations. Annual Review of Sociology, 21(1), 349-386. https://doi.org/10.1146/annurev.so.21. 080195.002025 .

Publisher's note Springer Nature remains neutral with regard to jurisdictional claims in published maps and institutional affiliations. 